\title{
Explanatory model of consumer purchase intention in digital social networks
}

\author{
Luz Lisset Oblea Ocampo \\ luz.oblea@edu.uag.mx \\ Gabriela Carranza Ortegón \\ gabrielacarranz@gmail.com \\ Universidad Autónoma de Guadalajara \\ Guadalajara, Jalisco. México
}

\begin{abstract}
The present research work addresses the impact of the influence and involvement of online experience exchanges among consumers of digital social networks, the commitment they manifest towards brands and the persuasive attitude towards advertisements. The study is contemplating Veblen social psychological theory as predictors of purchase intention. A theoretical-methodological model was developed at a confirmatory level, which is based on the Motivation, Opportunity, Capability model and the attitude model towards the brand and advertisement, alternative models for measuring purchase intention and commitment.

The objective of this research was to evaluate the attitudinal effect of consumers' purchase intention through the engagement model of consumers in digital social networks. The methodology used is quantitative, descriptive-correlational, cross-sectional applied in Mexico City, Guadalajara, Jalisco; Veracruz, Veracruz; Puebla, Puebla; Monterrey, Nuevo Leon; Villahermosa, Tabasco. The study population consisted of 140 consumers of cars, in car dealerships and users of social networks. The results of the study, were statistically processed at a confirmatory level, generating the proposed model with Patha analysis and the software SPSS and AMOS version 24.
\end{abstract}

Keywords e-WOM; social media; brand attitude; engagement; purchase intent 


\section{Modelo explicativo de la intención de compra en los consumidores en redes sociales digitales}

\section{RESUMEN}

El presente trabajo aborda el impacto que tiene la influencia e implicación de los intercambios de experiencias online entre los consumidores de redes sociales digitales, el compromiso que manifiestan hacia las marcas y la actitud de persuasión ante los anuncios. El estudio se encuentra contemplando la teoría de la racionalidad limitada de Simón, teoría de intercambio social de Homans y teoría psicológica social de Veblen, Figueras (2013) como predictores en la intención de compra. Se desarrolló un modelo teóricometodológico a nivel confirmatorio, el cual se fundamenta en el modelo motivación, oportunidad, capacidad y el modelo actitud hacia la marca y anuncio, modelos alternativos para la medir la intención de compra y compromiso.

El objetivo de esta investigación fue evaluar el efecto actitudinal de la inención de compra de los consumidores a través del modelo de actitud hacia las marca y anuncio, compromiso (engagement) con los intercambios de experiencias online, así como su motivación, oportunidad y habilidad de consumidores en redes sociales digitales. La metodología utilizada es cuantitativa, descriptiva-correlacional, de corte transversal aplicado en Ciudad de México, Guadalajara, Jalisco, Veracruz, Veracruz y Puebla, Puebla, Monterrey, Nuevo León, Villahermosa, Tabasco. La población estudio fue de 140 consumidores de autos en agencias automotrices y usuarios en redes sociales.

Los resultados del estudio fueron procesados estadísticamente a partir del modelo teórico, a nivel confirmatorio, con el análisis Path, procesado con los software SPSS y AMOS versión 24.

Palabras clave eWOM, redes sociales; actitud a la marca; compromiso; intención de compra.

Artículo recibido: 05 octubre. 2021 Aceptado para publicación: 02 noviembre 2021

Correspondencia: listeoblea@hotmail.com Conflictos de Interés: Ninguna que declarar 


\section{INTRODUCTION}

Organizations, regardless of their size and sector, carry out the administrative process through the preparation of strategic plans for the business that allow them to formulate strategies for changes and therefore, for the daily operations that allow them to meet their goals and objectives. Strategic management is the fundamental tool to carry out this process. It is defined as the art and science of formulating, implementing and evaluating cross-functional decisions that allow the organization to achieve its objectives. It integrates management, marketing, accounting, finance, production, logistics and warehousing, systems, and research and development for its success (David, 2003).

Communication processes between human beings are based on interaction to carry out their realization. These means are linked for communication, have been evolving, leaving behind the traditional ones such as: printed or massive in relation to the new formats of communication as the internet tool that are related to the advances of information technologies. The speed of interconnection with other people to share interests, preferences and tastes make the Internet the ideal medium for this action San José et al. (2012). Digital social networks are spaces for information exchange and generation of relationships between Internet users and are becoming increasingly relevant, as they enable interaction between people interested in common issues, sharing and exchanging knowledge, information, experiences, needs and interests Bigné (2013). The evolution of human communication from a technological approach and with the arrival of the XXI century, permeated in people by increasingly satisfy their need to interact to a greater extent, looking for more and more tools that allow them every day more improve their communicative process in different socioeconomic and cultural contexts in order to maintain the virtual way through digital technology (Work motivation and its impact on organizational performance in companies).

With the introduction of a digital environment, brands have new challenges such as the design of content for the transmission of information and that impact these users to remain. Through these social platforms, discussion forums and online pages, people can exchange information regarding a product, service or organization Norazah ( 2015). When this happened, it transformed the communication generated by the consumer, related to the product or service, it is known as electronic Word of mouth (electronic Word of mouth eWOM). In recent years, it has been shown that there is an effect of the 
communication that brands have of products and/or services through social networks on the purchase intention and loyalty of consumers to them. This implication has been studied in various researches considering the impact and influence of the brand on followers, the contents that are created by brands and the eWOM produced by the opinions of consumers in social networks Hsu (2017). It is emphasized that the origin, evolution and dissolution of social networks, develop consumer practices, as well as successfully influence their behavior and decisions. The consumer becomes the primary target of digital marketing trends (Rodriguez, 2017). Brands in this context, apart from the information that is transmitted, have new challenges to design content and impact on users who remain in social networks to find new formats and content that capture the attention of users of digital social networks (Bigné, 2012).

Companies are designing marketing strategies based on the development of this digital socialization process, which makes it possible to recognize the knowledge required to identify the needs of consumers, as well as the impact of the company's brand in order to obtain a sustainable competitive advantage in the market against the competition in the digital environment (San José et al., 2012). When this differential advantage in the environment occurs, it makes brand image a standard for companies. Brand image guidelines contain the rules that standardize the internal communication of the organization, as well as its planned external activities; in these documents, policies and actions are evaluated and adjusted to assess the impact on current and potential customers, in addition to improving brand positioning. One of the most popular trends in the area of digital marketing and brand building is the growth of social networks and their popularity among consumers (Schivinski, 2016).

According to many companies have started to maintain interactive relationships with people through brand follower pages or fan pages. In the last decade there have been several researches that have analyzed the effect of these communities in social networks on purchase intention and brand loyalty. In the literature, the independent variables analyzed that influence purchase intention have been diverse; engagement or commitment, content created by the brand, eWOM and the susceptibility of the followers of a Facebook page with the purchase intention of the brand (Laroche, 2017). The present study aims to understand the engagement of digital social media consumers with brands directly influences purchase intent. Likewise, persuasion in the attitude towards the brand 
contemplating Veblen social psychological theory influencing the purchase intention by consumers particularly in the automotive market (Martinez , 2015).

\section{Problem Statement}

In the world there are several automotive companies that compete with each other and share the global consumer market. Each brand has the necessary elements to identify itself in the communication directed towards consumers and therefore to have a certain level of positioning in the minds of consumers. Products can be identified, seeking to satisfy needs or benefits according to the specific attributes they offer Lee, (2008).

During the 80s and early 90s, Mexico had a number of automotive companies such as Chrysler, Ford, General Motors, Nissan, Renault, Vamsa and Volkswagen, to which Mercedes-Benz, BMW and Honda de México were added. With the implementation of the automotive section of the North American Free Trade Agreement (NAFTA), new brands were added to the automotive market, a process that continues to this day in an accelerated manner (Lee, 2008). There are currently more than 1,700 vehicle distributors in the country, marketing 42 brands, with an availability of around 300 models, totaling 1,400 versions of motor vehicles. In the sales report for the month of August 2020 of the Mexican Association of Automotive Distributors were one million 49 thousand 481 units as of August 2020, that is, the sum of the 12 months from September to August 2020. The ranking of brands in the commercialization of light vehicles from January to August 2020 is as follows; Nissan 20.4\%, General Motors 16.4\%, Volkswagen 10.3\%, Toyota $8.5 \%$, KIA $7.5 \%$, Honda $5.04 \%$, FCA $5.03 \%$ and the rest of the established brands with $26.9 \%$. These seven brands commercialize $73.1 \%$ of the total vehicles sold in Mexico.

A study was conducted in Mexico City, to determine how automotive brands are recognized by Mexican consumers. The results obtained allow us to affirm that each automotive brand is identified among consumers by quality and price. In addition, the ability of Mexican consumers to evaluate numerous automotive brands, according to these concepts was recognized. Lee (2008) mentioned that these results can support better planning of marketing strategies, so that automotive companies with their network of distributors operating in Mexico, can fine-tune more effective communication strategies to reach their target customers. This study analyzed how communication strategies in social networks impact brand management as a starting point; any organization or 
company that does not develop a brand communication strategy or policy is destined to be overtaken by the competition.

\section{Strategic Management}

Companies require tools that allow them to meet their objectives, despite their complexity, business line or industrial sector, size, formality, academic level of their personnel, stability in the market, among other variables, they require strategic management. Garrido (2006) defined that an important element of strategic management is the formulation of the strategy, he mentioned that strategy planning implies a synthesis, which implies the art and technique in which the strategist must decide and negotiate the dynamic way to handle uncertainty, ambiguity and negotiation scheme. He also mentioned that strategy planning implies a synthesis, which is a technique and art in which the strategist or actor must decide and negotiate dynamically handling uncertainty, ambiguity and negotiation possibilities.

Daft (2011) mentioned that a strategy is the action plan that describes resource allocation and activities to face the environment and achieve the organization's goals. Strategic management is a systems approach process of evaluating the nature of a business, defining long-term objectives, identifying quantitative goals and objectives, developing strategies to achieve these objectives and locating resources to carry out these strategies (Thompson, 2012). To establish a competitive advantage, four fundamental elements are considered: superiority in efficiency, quality, speed, flexibility and innovation, and responsiveness to customers (Robbins, 2013). For companies, knowledge is an important input, since through the understanding of consumer behavior it is possible to identify tastes and needs important to people, in addition to providing answers to the questioning of companies about the buying motivations of consumers: why they buy, how much they buy, how often they buy and all the variables that influence consumption decisions in the same sense, the information is valuable to design strategies that impact sales through the internet, by identifying the reference groups whose behaviors and opinions, it is possible to influence (Jones and George, 2014).

\section{Theory of Thorstein Bunde Veblen}

The social-psychological model of Thorstein Bunde Veblen is conceived in the theory of consumption based on habits included in the theory of the idle class of 1899 , as well as the theory of economic cycles and crises that he developed in the Theory of the business 
enterprise of 1904. Man is considered as a social animal adapted to the norms and general forms of his culture. Veblen criticized orthodox economics for being based on a deficient psychology. He considered that human beings are guided by instincts and habits, among which selfishness is only one of them. He also explained that the place of hedonism in the discipline of economics was an elusive way of studying the complexity of human motivations. He attributed the use of this basic assumption to intellectual laziness. His criticism was not based on the use of egoism in social reality, but on the excessive importance given to it by received economics. He sought to demonstrate that human behavior associated with various motivations, such as emulation, instinct for efficient work, idle curiosity, instinct for self-preservation, and parental inclination.

Veblen considered that the received economy conceived man as a passive entity that is affected by the exterior identifying pains, pleasures and determined the importance of the motivations of human beings that define mentalities and behaviors. He focused on two fundamental aspects; the motivations of consumers and social change. On the other hand, they identified in the study of motivations, that Veblen adopted a broader psychological approach, stating that man acts guided by five instincts: that of efficient work, emulation, or tendency to follow the behavior of the reference group and imitate that of peers, that of idle curiosity or inclination to disinterested knowledge; that of paternal inclination which implies concern not only for their own present welfare, but also for the future of their offspring, and that of self-preservation Figueras ( 2013).

Likewise, he considered in the idle theory as an economic factor the idle class that influences the behavior patterns and consumption habits of the whole society. Likewise, he elaborated a theory of consumption based on emulation and the instinct to work, which he contrasts with the vision of an automaton consumer who assumes utility with foresight. A person's reputation or prestige is related to the social patterns or standards associated with individual prowess or feat, the signs on the basis of which a person is catalogued and socially esteemed. As consumption is the basis of social and individual esteem, the individual develops the habit of seeking expressions within a certain line of honorary spending, thus consumption patterns become habits and are difficult to change. Every individual seeks self-improvement and therefore determines his consumption based on the next level of the immediate superior class, imitating their patterns of behavior. From 
this new perspective, respect and conventions that are linked to a higher reputation are sought.

The purchases that an individual make may be motivated by social class influences and the desire to belong to a certain group of interest. In such a way that the consumption behavior of the person is affected by the prestige of the product and/or service, because those that enjoy greater prestige in the group, community or society where he/she lives are desirable, factors such as family, culture and reference groups, can significantly influence consumer behavior.

The desire for greater comfort and security in the face of need is present in each and every stage of modern industrial society, although it is largely affected by the habit of emulation, which allows modeling methods and selects objects of expenditure for comfort and life with respect Figueras (2013).

\section{Engagement}

Engagement offers an improvement in the current theories on the relationship between consumers and brands, based on the roots of relationship marketing (Fournier, 1998). The engagement or loyalty of a brand's followers on Facebook influences all phases of the buying process: cognitive phase, affective phase and conative phase. They argued that engagement influences brand awareness, because social networks generate a way of exposing the brand to consumers, therefore, engagement influences the initial stage of the purchase process (Hutter, 2013).

A brand in social networks is conceptualized as a multidimensional construct composed of three dimensions: cognitive, affective and conative (Hollebeek, 2014). The added value of engagement lies in supporting interactions and experiences in consumer relationships and influencing different purchase situations (Vivek, 2012). The affective dimension includes enthusiasm towards the community and the brand, and the enjoyment of interactions with them, the cognitive dimension includes the conscious and voluntary decision to invest time to connect with the community and the behavioral dimension includes participation, through active learning, sharing and endorsing behaviors of others (Dessart, 2015). Engagement was defined as the emotional links between consumers and brands. It was mentioned that positioning is not focused on reasoning but on emotions, it seeks a relationship in both directions, making engagement the degree to which the consumer interacts with a brand, the commitment between the brand and the users is 
evidenced on the basis of the branded content found in the experiences offered. There are many ways to show the love or affinity that a person may have with a particular brand, through social networks such as Facebook fanpage with a like, following the official accounts of brands or sharing videos (Müller, 2017).

\section{Electronic Word of Mouth (e-WOM)}

Electronic word-of-mouth (e-WOM) is defined as any positive or negative statement made by potential, current or former customers about a product or company, which is made available to a multitude of people through the Internet (Hennig-Thurau, 2004). This definition includes communication between vendors and consumers, as well as between consumers themselves. Its typology is two-dimensional: 1) by the scope of communication; one-to-one (e-mails), one-to-many (opinion portals) or many-to-many (virtual communities). 2) By the level of interactivity: from asynchronous (e-mail, opinion portals, blogs) to synchronous (chats, forums, instant messaging). On the other hand, although electronic word-of-mouth is considered more persuasive and more desired by consumers than content generated by brand managers, it is important to highlight that compared to other sources of information, word-of-mouth is considered more persuasive and more desired by consumers than content generated by brand managers Lee; It is important to highlight that compared to other sources of information, word-of-mouth is considered more persuasive and more desired by consumers than content generated by brand managers Lee (2008). Consumers who are highly loyal are more likely to positively express WOM for the brand and act as brand advocates. In the same vein, communication among consumers through social networks has become one of the most widely used digital media of the existing electronic word-of-mouth formats and user-generated content has originated new information review habits in those consumers who take an active role in their purchasing decisions have changed the way consumers make purchasing decisions, as they can easily and quickly exchange product-related information and opinions with personal contacts Chiu, (2015).

\section{Purchase intention}

The purchase intention is established as a decision making on the part of consumers and focuses on solving a problem. When a consumer tends to perceive a problem and focuses their attention on solving it, adopts and disposes of all measures to try to identify what they are looking for and chooses the means to obtain a product and / or service, usually 
coincides with the actual subsequent purchase Fishbein (1975) there may be situations in which the intention does not involve a subsequent actual purchase. The factors that affect in consumer purchase decision making are complex, so the study of consumer behavior is related to psychology and sociology Torres, (2013).

It is explained that each person is different, so it is important to provide an instrument to explain how purchasing decisions are made Martinez (2006). As this situation manifests itself, companies take advantage of this need, developing brand positioning strategies in order to identify the degree of importance given in the mass consumption of certain brands and being the main target to buy. The stages of the purchase intention in which the consumer incurs the first stage occurs at the time of seeking to acquire a product and / or service is the recognition of the need, the second stage is when consumers must seek information and is to be clear about the degree of importance of the purchase decision either to satisfy a need or an expectation. In the third stage, is the evaluation of alternatives, where consumers pay all their attention to the assessment to make the best decision according to the search previously made Santos (2020).

\section{METHOD}

A theoretical-methodological model was developed at a confirmatory level by Path analysis which is based on and adapted from the following models: engagement or commitment model through empirical evidence; Wu (2011), Huang et al. (2009) and Hsu (2017). Alternative models for measuring purchase intention such as Calvo-Porral (2013) and Schivinski and Dabrowski (2013) were the support to carry out the proposed model to test the influence of digital social networks on the brand and purchase intention. The methodology elaborated for the development of the research followed the order of type of study, study population, sampling method, operationalization of variables, measurement instruments for data collection and data analysis. A quantitative, descriptive, correlational and cross-sectional research was carried out, since the association or relationship between variables that have been quantified was studied, which helped more in the interpretation of the results of a sample in a certain time. This allows inferences in a population where the study sample was obtained and therefore the answer to the research question and testing of hypotheses Maclnnis, et al. (1991), Gruen et al. (2007). 
The study is subject to certain limitations. First, to consumers who buy cars from car dealerships and use social networks (Facebook) established in Mexico City, Guadalajara and Veracruz, the sample size that in an estimated time span of three months. The use of five-chord Likert scales.

\section{Sample profile}

The working universe is automotive dealerships and their customers in Mexico City, Jalisco, Veracruz, Puebla, Estado de México, Morelos, Nuevo León and Tabasco. The sample was taken from the database of customers attending automotive agencies in Mexico City, the municipalities of Naucalpan, Cuautitlán Izcalli, Tlalnepantla, Atizapán de Zaragoza; the states of; State of Mexico, Puebla, Puebla, Cuernavaca Morelos, Monterrey Nuevo Leon, Guadalajara Jalisco, Boca del Rio, Veracruz, Orizaba, Cordoba, Xalapa, San Andres Tuxtla, Veracruz and Villahermosa Tabasco, for the acquisition of an automotive unit, automotive service or purchase of spare parts.

The sample size calculated as follows; from the universe of the research, the number of automotive agencies belonging to the Mexican Association of Automotive Distributors of Mexico (AMDA), an organization where the networks of automotive agencies of the brands established in the national market belong, obtained. The average monthly sales in car dealerships in these states is 1,083 cars/customer. The finite population formula (less than 500,000), used to calculate the sample size.

Calculating a sample of 144 customers/cars.

\section{Coding procedure and categories.}

The methodology elaborated for the development of the research followed the order of type of study, study population, sampling method, operationalization of variables, measurement instruments for data collection and data analysis. A quantitative, descriptive, correlational and cross-sectional research was carried out, since the association or relationship between variables that have been quantified was studied, which helped in the interpretation of the results of a sample in a certain period of time. The study is subject to certain limitations. Firstly, to consumers who buy cars from automotive agencies and use social networks (Facebook), the sample size that in an estimated time span of three months. The use of five-chord Likert scales.

- Based on the calculation of the sample size of 144 customers of the car dealerships, the data collection instrument was delivered. 
- The online survey was carried out using the Qualtrics platform, a research support tool provided by the Universidad Autónoma de Guadalajara.

- The construction of the questionnaire was carried out through the thorough examination of other data collection instruments that two constructs measured in the model are engagement and purchase intent.

- The data collection instrument was validated and a pilot test was applied. The behavior of the engagement and purchase intention dimensions was identified.

- The reliability analysis of the data was carried out using the Cronbach's Alpha statistic, obtaining 0.778 for engagement and 0.708 for purchase intention, both being optimal above 0.7 (Hair, 2009).

- The exploratory analysis of the instrument was performed by construct, for which the Kaiser-Meyer-Olkin measurement test (KMO) and Barlett's test of sphericity were used. The extraction test used maximum likelihood (MLV) without rotation due to the unidimensionality of the constructs.

- The Kaiser-Meyer-Olkin (KMO) sample adequacy test was used, obtaining 0.742 for purchase intention and 0.882 for engagement, both being optimal according to the appropriate value of 0.7 , so the measure the homogeneity of the variables and the contribution to the degree of explanation of the questionnaire items (Hair, 2009).

- Likewise, the AVE composite validity was calculated whose optimal value is 0.5 , giving 0.5042 for purchase intention and 0.500 for engagement.

A descriptive analysis was used to identify the descriptive characteristics of the study clients in the sample. Frequency tables were used for nominal data such as gender, age, education. (Table 1)

Table 1.

Descriptive análisis Gender

\begin{tabular}{|ll|}
\hline Gender & Porcentage \\
Male & $66.4 \%$ \\
Female & $33.6 \%$ \\
Total & $\mathbf{1 0 0 \%}$ \\
\hline
\end{tabular}

Source. Own elaboration based on data from SPSS24 software. 
Subsequently, in relation to the age of the participants, the composition of the sample was: less than 20 years old 7.1\%, 21 to 25 years old $11.4 \%, 26$ to 30 years old $5.7 \%, 31$ to 40 years old $22.9 \%$ and 41 years old and over $52.9 \%$. (Table 2).

Table 2.

Descriptive analysis Age.

\begin{tabular}{|lc|}
\hline Age & Percentage \\
\hline Less than 20 years old & $7.1 \%$ \\
21 to 25 years old. & $11.4 \%$ \\
26 to 30 years old. & $5.7 \%$ \\
31 to 40 years old. & $22.9 \%$ \\
41 years and older & $52.9 \%$ \\
Total & $\mathbf{1 0 0 \%}$ \\
\hline
\end{tabular}

Source. Own elaboration based on data from SPSS24 software.

In reference to the level of education of the participants, the sample was made up of $0.7 \%$ secondary school, $10.7 \%$ high school, $37.9 \%$ undergraduate and $50.7 \%$ graduate, allowing us to conclude that the sample has an elevated level of education. Participation in social networks by the sample classified as follows: less than 6 months $4.3 \%, 1$ to 2 years $0.7 \%, 2$ to 3 years $11.4 \%, 3$ to 5 years $16.4 \%$ and more than 5 years $67.1 \%$, detecting a sample with experience in the management of social networks. The results obtained for the frequency of connection to social networks by the participants in the study were: more than twice a day $55 \%$, once or twice a day $10.7 \%$, several a week $14.3 \%$ and once a month $20 \%$.

\section{ANALYSIS AND RESULTS}

For the testing of the hypothesis that the engagement of consumers of digital social networks to brands directly influences the purchase intention. A PATH analysis (PA) was carried out with a multivariate model using AMOS 24 software. This multivariate method was used to adjust causal models and to identify the direct and indirect contribution made by a set of independent variables to explain the variability of the dependent variables. The results obtained from the PATH analysis in AMOS 24 allowed the testing of the hypotheses from the regression weights analysis in model fit. the ratio of commitment and intention to purchase was obtained as C.R. 3.578, P 0.000, S.E. 0.058. In relation to the analysis of goodness of fit; CFI value 1.0 being greater than 0.95 . RMSEA value 0.00 
being lower 0.08 , goodness of fit index GFI value 1.00 being higher 0.95 . With these results the null hypothesis is rejected where it is defined that the engagement of consumers of digital social networks to brands does not directly influence the purchase intention therefore the research hypothesis that mentions that the engagement of consumers of digital social networks to brands does directly influence their purchase intention is accepted Hsu (2017), Aaker (1996). The results of the research have shown that companies must implement in their strategies a communication link between brand and user in a bidirectional way, in attention to the user's habits and demands and attending to the digital context where they are.

Digital social networks are an attractive channel that brands need to be active through its image, virality, listening dynamically to users, conversing with an appropriate segmentation that allows the involvement of users, thus generating an effective communication channel that allows a follow-up to convert users into customers and digital social networks generate their activity and much of their interactivity based on the collaboration and free consideration of users, with little or no filtering or selection Tuñez (2010).

It has been shown by the results that the response that users have towards brands and advertisements displayed, impacts on their subsequent conversations their commitment to the brand that is published in digital social networks in this case Facebook, checking their behavior and the effect it has on their subsequent consumption.

\section{DISCUSSION AND CONCLUSIONS}

The problem posed in this research, was solved through structural equation modeling (SEM). The confirmed theoretical model allows us to answer the following research questions. The question Is, the purchase intention of consumers in digital social networks, confirmed as an attitudinal effect of the Engagement model? It is confirmed that consumers' purchase intention has an attitudinal effect relationship based on the model Algesheimer ,R., et, al. (2005), which proposes that the consumer's relationship with the brand, is established based on identification with the community, which affects the user's commitment to the community.

The identification with the community is stated as the strength of the relationship that exists between the consumer and the community. 
Engagement with the brand community, refers to the positive influences to identify with the brand community being intrinsic motivations to interact and cooperate with community members. If the perceived influence is positive by community users, they help each other by participating more actively. The consumer experiences a social pressure to be a member and is related to the norms that ultimately influence their behavior. If the consumer is committed to the brand community, the greater the obligation to contribute and defend it. Bigné et, al (2005).

This research was conducted with the purpose of evaluating the attitudinal effect of consumers' purchase intention through customer engagement with brands posted on digital social networks. The measurement instrument for data collection was validated, being a methodological contribution of this research. In the research process, a sample of customers who directly purchased cars through automotive distributors of different brands that manage digital social networks was contemplated, which provided objective information on the perception of comments on digital social networks and their influence on the intention to purchase a car.

The results of the research reflect that for the sample under study, the commitment or engagement is linked to a series of behaviors that lead to the purchase action as a result of individual and collective motivations that generate a determining effect on the performance of the brands. Engagement is relevant because it has consequences for the brand as it contributes to increase the value of the most valuable asset, which are the customers. The attitude of purchase intention of consumers in digital social networks is based on the theory of Veblen, which emphasizes the consumption practices, taste formation and its relationship with social institutions, being in the field of digital social networks such as facebook is a factor that influences the patterns and habits of consumption based on the value between social classes, where the reputation or prestige of a person is related to the patterns or social standards from which it is cataloged, motivating the estimation of the person who has a good reputation becoming an opportunity references and honorability of actions. The purchase intention was confirmed as a determinant effect produced by the consumer and their commitment (engagement) towards the brand, being their attitude towards it, the advertisements, the exchange of experiences produced by their motivation, the opportunity to carry them out and their ability to express themselves in digital environments. Digital social networks are 
becoming more relevant every day with frequent use recognizing that $80 \%$ of Internet users have made online purchases in recent years. Also 9 out of 10 seek to compare products and prices online to make any purchase as well as pay attention to the ads and makes them relevant in social networks.

Given this, companies should consider in their digital brand strategies to participate more actively, generating engagement with users, collecting information about users who participate in them. The company's social network profile should be entertaining and fun, becoming the main objective of the communication strategies of the companies in the digital environment, thus improving the user's commitment to the brand, their attitude towards the communication strategies designed, exchanging comments with other users that ultimately leads to their intention to purchase the products and / or services of the company

\section{REFERENCES}

2020, R. d. (s.f.). www.amda..mx.

2020, Reporte de ventas del mes de agosto. (2020). Asociación Mexicana de Distribuidores Automotores A.C. Recuperado el septiembre de 2020, de AMDA: https://www.amda.mx/

Aaker, D. (1992). El valor de la marca. Journal of bussiness stategy., 27 -31.

Aaker, D. (1996). Managing Brand Equity: capitalizing on the value of brand name. California Management Review, 28(3), 102-120.

Aaker, D. (1996). Measuring brand equity across products and markets. California management Review, 102-120.

Algesheimer R., Dholakia, U. y Hermann, A. (2005) The social influence of brand community:evidence from European car clubs, Journal of Marketing, 69(7), 19-34.

Algesheimer R., Dholakia, U. y Hermann, A. (2005) The social influence of brand community:evidence from European car clubs, Journal of Marketing,69(3), 19-34.

Aguado, G. y. (2009). Del Word-of- Mouth al Marketing viral: aspectos claves de la comunicación a través de redes sociales. Comunicación y Hombre, 7(5), 41-51.

Anderson, E. y. (1993). Los antecedentes y las consecuencias de la satisfacción del cliente para las empresas. Ciencias del Marketing, 12 (2), 125-143. 
Bigné Alcañiz, j. E., Andreu Simó, L., Sánchez García, I., \& Alvarado Herrera, A. (2005). Investigación internacional en marketing turístico: análisis de contenido sobre temas y metodologías. PASOS Revista De Turismo Y Patrimonio Cultural, 6(3), 391-398.

Bigné E., K. I. (2013). Las redes sociales virtuales y las marcas: influencia del intercambio de experiencias eC2C sobre la actitud de los usuarios hacia la marca. Revista Española de Investigación de Marketing ESIC, 7-27.

Bigné, E. y. (2012). Does Web Site Engagement Lead To Making A Purchase? Summer Educators' Conference. Chicago: American Marketing Association.

Blau, P. (1964). Exchange and power in social life. New York: Wiley.

Calvo-Porral, C. ,. (2013). Análisis de dos modelos de ecuaciones estructurales alternativos para medir la intención de compra. Revista Investiación Operacional, 34(4), 230-243.

Chiu, W. K. (2015). Customers as partial employees: The influences of satisfaction and commitment on customer citizenship behavior in fitness centers. Journal phys. educ. sport., 627-633.

Daft, R. (2011). Teoría y Diseño Organizacional. México: Cengage Learning.

David, F. (2003). Conceptos de Administración Estratégica. (E. Q. Duarte, Ed.) Naucalpan de Juárez, Estado de México, México: Pearson Educación.

David, F. R. (2003). Conceptos de Administración estratégica. Pearson Prentice Hall.

Dessart, L. V.-T. (2015). Consumer engagement in online brand communities: a social media perspective. Journal of product and brand management, 24(1), 28-42.

Figueras, A. (2013). La teoría del consumo y de los ciclos en Thorstein Veblen. Revista de economía institucional, 15(28), 159-182.

Fishbein, M. A. (1975). Creencia, actitud, intención y comportamiento: una introducción a la teoría y la investigación. Addison-Wesley.

Fournier, S. (1998). Consumers and their brands: developing relationship theory in consumer research. journal of consumer research, 24, 343-369.

Garrido, S. (2006). Dirección estratégica. España: Mc Graw Hill.

Gruen, T., \& Osmonbekov, T. y. (2007). Customer to customer exchange: its MOA antecedents and its impact on value creation and loyalty. Journal of the academy of marketing science, 35(4), 537-549.

Hair, J. (2009). Multivariate data analysis . New Jersey: Prentice Hall. 
Hennig-Thurau, T. G. (2004). Electronica word of mouth via consumer opinion plataforms: What motivates consumers to articulate themselves on the internet? Journal of interactive marketing, 38-52.

Hollebeek, L. ,. (2014). Consumer brand engagement in social media: conceptualisation, scale development and validation. Journal of interactive marketing, 28(2), 149165.

Homans, G. (1967). Social Behavior : its elementary forms. Harcourt, New York.: The nature of social science.

Hoyer, W. D. (2012). Comportamiento del consumidor. Cengage learning.

Hsu, C. (2012). A Customer-Based Brand Equity Model for Upscale Hotels. Journal of travel research, 51(1), 81-93.

Hsu, L. (2017). Investigating community members purchase intention on Facebook fan page: From a dualistic perspective of trust relationships. Industrial Management and Data Systems,. Journal of product and Brand Management, 766-800.

Hsu, L. K. (2018). Investigando la participación y promoción de la comunidad virtual desde una perspectiva de influencia social. Gestión industrial y sistemas de datos., $118(6), 1229-1250$.

Hutter, K. ,. (2013). El impacto de las interacciones de los usuarios en las redes sociales en el conocimiento de la marca y la intención de compra: el caso de MINI en Facebook. Journal of product and brand management, 342-351.

Jones, G., \& George, J. (2014). Administración contemporánea. México: McGraw Hill.

Kim, A. J. (2016). Power of consumers using social media:examining the influences of brand related user generated content on facebook. Computers in human behavior, 98-108.

Kim, A. y. (2012). Impacts of luxury fashion brand's social media marketing on customer relationship and purchase intention. Journal of Global Fashion Marketing, 1(3), 164-171.

Laroche, M. y. (2017). Analyzing electronic word of mouth: A social commerce construct. International Journal of Information Management.

Lee, J. P. (2008). The effect of negative online consumer reviews on producto attitude : an information processing view. Electronic Commerce Research and Applications., 7(3), 335-341. 
Martínez, J. (2006). Mecanismos cerebrales de la toma de decisiones. Revista de Neurología., 42, 411-418.

Martínez, O. R. (2015). El comportamiento del consumidor en internet bajo el modelo social Veblen. Revista Global de Negocios., 101-112.

Müller, O. J. (2017). The impact of content, context and creator on user engagement in social media marketing. System Sciences, 1152-1161.

San José Cabezudo, R., Camarero Izquierdo, C., \& Rodríguez Pinto, J. (2012). En busca de los evangelizadores digitales: Por qué las empresas deben identificar y cuidar a los usuarios más activos de los espacios de opiniones online. Universia Business Review, 14-31.

Santos, I. (2020). El comportamiento del consumidor y las nuevas tendencias de consumo ante las TIC. ESIC Market Economics and Business Journal, 50(3), 621-642.

Schivinski, B. D. (2016). The effect of social media communication on consumer perceptions of brands. Journal of Marketing Communications, 1-24.

Simon, H. (1967). Motivational and emotional controls of cognition. Psychological Review, 74(1), 29-39.

Simon, H. (1986). The information processing explanation of gestalt phenomena. Computers in human behavior, 2(4), 241-255.

Simon, H. (1991). Nonmonotonic reasing and causation. Cognitive Science, 15(2), 293300. Obtenido de scielo.org.

Simon, H. (1991). Organizations and markets. The journal of economic perspectives., 2544.

Simon, H. (1991). Organizations and Markets. The journal of Economic perspectives, 2544.

Thompson, A. G. (2012). Administración estratégica, teoría y casos. México: McGraw Hill.

Torres, D. ,. (2013). Medición de la intención de compra con base en un modelo de regresión logística de productos de consumo masivo. Revista latinoamericana de Comercio, 45-60.

Tuñez, M. J. (2010). Del aula a las redes sociales: el uso de facebook en la docencia universitaria. Congreso Internacional latina de comunicación social . http://www.revistalatinacs.org/10SLCS/actas_2010/001JoseSixto01.htm. 
Vivek, S. S. (2012). Compromiso con el cliente: exploración de las relaciones con el cliente más allá de la compra. The journal of marketing theory and practice, 20(2), 127-145.

$\mathrm{Wu}, \mathrm{C}$. Y. (2011). The effect of store image and service quality on brand image and purchase intention for private label brands. Australian Marketing Journal, 19(1), 30-39. 